\title{
Acid sphingomyelinase inhibitors, imipramine and zoledronic acid, increase skeletal muscle tissue sensitivity to insulin action at old age
}

\author{
Loay Kh. M. Hassouneh, Olga A. Timofiychuk and Nataliya A. Babenko \\ Department of Physiology of Ontogenesis, Institute of Biology, Kharkov Karazin National University, 4 Svobody pl., Kharkov, \\ 61022, Ukraine
}

\begin{abstract}
Malfunction of skeletal muscles and dysregulated turnover of sphingolipids in the insulin responsive tissues have been determined at old age. Present article investigates the role of acid sphingomyelinase (SMase)-dependent ceramide accumulation in reduction of the skeletal muscle sensitivity to insulin action at old age. The 3-, 12- and 24-month-old Wistar male rats were used in the experiments. The progressive increase of ceramide content and ceramide/sphingomyeline (SM) ratio was determined in the extensor digitorum longus (EDL) muscle during aging of rats. The agedependent ceramide accumulation was followed by reduction of muscle tissue response to insulin action. The resistance of EDL to insulin action at old age can be imitated by exogenous natural $\mathrm{N}$-palmitoyl-D-erythro-sphingosine (C16-ceramide) injection to adult rats, while imipramine or zoledronic acid treatment of old animals nullified dysregulation of SM turnover and improved the muscle tissue response to insulin action. Drugs significantly increased insulin-stimulated 2-D- $\left[{ }^{3} \mathrm{H}\right]$ glucose uptake by the EDL muscle of 24-month-old animals to the level close to that of 3-month-old rats in both in vivo and in vitro experiments. Imipramine, as well as zoledronic acid significantly reduced acid SMase activity in the EDL of old animals. Thus, ceramide overproduction via acid SMase activation can be important for the development of EDL resistance to insulin action. Therefore, acid SMase inhibitors can possibly be used as therapeutic tools for improvement of muscle tissue sensitivity to insulin action at an old age.
\end{abstract}

Key words: Acid sphingomyelinase inhibitors - Skeletal muscle — Aging — Insulin-stimulated glucose uptake

\section{Introduction}

Acid sphingomyelinase (SMase) is a key enzyme of sphingolipid turnover. The main products of SMase activity are ceramides, which are signaling molecules and important components of lipid rafts. Activation of acid SMase has been determined under the action of various cellular stressors and inflammatory cytokines, which may play a role in insulin resistance (Summers 2006; Cawthorn and Sethi 2008; Jenkins et al. 2010). Moreover, ceramide accumulation in the insulin responsive tissues are usually associated with

Correspondence to: Nataliya A. Babenko, Department of Physiology of Ontogenesis, Institute of Biology, Kharkov Karazin National University, 4, Svobody pl., Kharkov, 61022, Ukraine

E-mail: babenko@univer.kharkov.ua vatramentov@gmail.com reduced sensitivity to insulin action (Chavez and Summers 2003; Holland and Summers 2008; Summers 2010; Lipina and Hundal 2011). Increased production of ceramides and inflammatory cytokines has been correlated with reduced liver and brain cell sensitivity to insulin action at old age (Babenko and Kharchenko 2012, 2015a, 2015b, 2015c). Ceramides can inhibit numerous key points of insulin signaling pathways such as protein kinase Akt, glucose transporter 4 (Glut4) and phospholipase D. Obesity-induced insulin resistance is usually associated with an increase of ceramide synthesis de novo and can be improved by the inhibitor of sphingolipid synthesis, myriocin (Holland et al. 2007). However, improvement of liver cell sensitivity to insulin action at an old age can be done only by the mixture of myriocin and inhibitors of neutral and acid SMases (Babenko and Kharchenko 2015a). Treatment of isolated "old" liver cells by inhibitor of key enzyme of 
sphingolipid synthesis de novo (serinepalmitoyltransferase (SPT)) myriocin and inhibitors of neutral (GW4869) and acid SMases (imipramine) abolishes age-dependent ceramide accumulation and improves hepatocytes sensitivity to insulin action (Babenko and Kharchenko 2015a). However, in the brain cortex and hippocampus of 24-month-old rat neutral SMase-dependent ceramide accumulation has been determined (Babenko and Shakhova 2014a). Neutral SMase inhibitors nullify age-dependent changes of sphingomyeline (SM) turnover, while imipramine treatment of old rats does not change the ceramide content in the brain. It can be assumed that neutral SMase-induced ceramide accumulation in brain structures at old age led to brain resistance to insulin action. However, little is known about mechanism of age-dependent ceramide accumulation in the skeletal muscle which is a main insulin-responsive tissue.

Different pathways of ceramide production have been demonstrated in the muscle tissues (Błachnio-Zabielska et al. 2010, 2011). SPT, neutral and acid SMase, neutral and alkaline ceramidases (nCDase and alCDase) play an important role in maintaining specific levels of ceramide in the soleus and red and white sections of gastrocnemius muscle. It has been demonstrated that elevated ceramide content in the muscle tissues induced by the diet enriched with saturated fat (SFD) could be a result of increased SPT activity and decreased activity of nCDase. At the same time, diet enriched with the polyunsaturated fat did not change ceramide content in the skeletal muscle due to increased activity of SPT and alCDase and decreased activity of SMases. Elevated ceramide level in the soleus and gastrocnemius muscle of rats on SFD resulted in reduction of insulin-stimulated glucose uptake (Błachnio-Zabielska et al. 2010). Moreover, a two-fold increase of ceramide level in the skeletal muscle of obese humans was observed to decrease Akt phosphorylation after an insulin infusion and thus, could play an important role in the reduced ability of insulin to stimulate glucose uptake (Adams et al. 2004). Recent experiments using cultured myotubes and permeabilized red gastrocnemius muscle fiber bundles showed that exogenous and endogenous ceramides increased mitochondrial fission associated with reduced mitochondrial respiration and increased production of reactive oxygen species (ROS). Also, it was found that mitochondrial fission is important in ceramide-induced insulin resistance (Smith et al. 2013). Using myriocin, the inhibitor of the rate-limiting enzyme in ceramide biosynthesis, it has been determined that newly synthesized ceramide in the red gastrocnemius muscle affect both mitochondrial respiration and glucose tolerance in mice fed a high-fat, high-sugar diet. In addition, dietinduced accumulation of the newly synthesized ceramide in the skeletal muscle plays an important role in reduction of cell sensitivity to insulin action due to inhibition of Akt phosphorylation and activity and mitochondrial dysfunction. It is also demonstrated that inhibition of acid SMase activity by specific enzyme inhibitors reduces ceramide level in such skeletal muscles as soleus and gastrocnemius of old rats (Babenko et al. 2016). However, the role of acid SMasedependent ceramide accumulation in the development of insulin resistance in muscle tissue should be determined. Taking into account that insulin signaling is similar in all classical insulin-sensitive tissues and ceramide induces insulin resistance via inhibition of key points of insulinreceptor signal cascade an assumption can be made that acid SMase-dependent ceramide accumulation at old age leads to a decrease of skeletal muscle sensitivity to insulin. If so, the new target for treatment of muscle tissue resistance to insulin action at old age will be determined.

The aim of the present work was to determine the impact of acid SMase hyperactivity in the intramuscular ceramide accumulation and reduction of the extensor digitorum longus muscle tissue response to insulin action at old age. For this purpose two inhibitors of acid SMase, imipramine and zoledronic acid, were used. These inhibitors have different mechanisms of action on SMase, minimally toxic, widely used to improve the acid SMase-dependent metabolic dysfunctions and licensed for medical use in humans (Kölzer et al. 2003; Roth et al. 2009; Arenz 2010; Jenkins et al. 2010; Kornhuber et al. 2010; Canals et al. 2011).

\section{Materials and Methods}

\section{Materials}

Imipramine hydrochloride ("Melipramin" Egis, Hungary), zoledronic acid ("Zometa", Novartis Pharma Stein AG, Switzerland), [N-methyl- ${ }^{14} \mathrm{C}$-phosphorylcholine] sphingomyelin (52 $\mathrm{mCi} / \mathrm{mmol}$ ) ("PerkinElmer", USA), sodium chloride ( $0.9 \% \mathrm{NaCl}$ injectable solution, Galich Farm, Ukraine), Sorbfil plates (Sorbopolimer, Russia) for thin-layer chromatography were used. Lipid standards (ceramide, SM) were obtained from Sigma (USA). Other chemicals used were of chemically pure grade.

\section{Animals}

The 3-, 12- and 24-month-old Wistar male rats were used in the experiments. They were kept at $24^{\circ} \mathrm{C}$ on a cycle of $12 \mathrm{~h}$ light $/ 2 \mathrm{~h}$ darkness and had a free access to a standard chow diet and drinking water ad libitum. All experiments on animals were carried out according to the International Principles of the European Convention for the Protection of Vertebrate Animals Used for Experimental and Other Scientific Purposes (Strasbourg, 1985) and National General Ethical Principles for Experiments on Animals 
(Ukraine, 2001). Experimental procedures were approved by the Institutional Animal Care and Use Committies at the Kharkov Karazin National University. The 3-month-old rats were divided into 2 groups: C16-ceramide intraperitoneally injected ( $40 \mu \mathrm{g}$ per $\mathrm{kg}$ body weight) for 6 days and control group. Control rats were intraperitoneally injected for 6 days with a mixture of ethanol and dodecane $(49: 1, \mathrm{v} / \mathrm{v})$ diluted in warm $0.9 \%$ sodium chloride. The 24 -month-old rats were divided into four groups: imipramine- and zoledronic acid-treated and two control groups. The 24-month-old rats injected by imipramine, intramuscularly, daily for 14 days (10 mg/kg body weight) and rats injected by zoledronic acid, intramuscularly ( $0.15 \mathrm{mg} / \mathrm{kg}$ body weight) for 10 days, one time in two days. Control rats (for imipramine-treated) intramuscularly injected by $0.9 \% \mathrm{NaCl}$ daily for 14 days. Control animals (for zoledronic acid-treated) intramuscularly injected by $0.9 \% \mathrm{NaCl}$ for 10 days, one time in two days. Rats were fasted overnight and were anesthetized the next day with an injection of ketamine $(75 \mathrm{mg} / \mathrm{kg})$ and sacrificed by decapitation. Their skeletal muscle tissues (extensor digitorum longus) were used for lipid analysis, determination of acid SMase activity and insulin-induced glucose uptake as described below.

\section{Experiments with muscle tissue}

Extensor digitorum longus muscles were widely used to study muscle insulin sensitivity. Muscles were quickly removed and dissected on ice. Isolated muscles were washed in Krebs-Ringer bicarbonate buffer, $\mathrm{pH}$ 7.4. Homogenates of the muscles, prepared in the Krebs-Ringer bicarbonate buffer, $\mathrm{pH} 7.4$, were used for lipids extraction and separation as described below. Isolated muscle strips of 24-month-old rats were incubated in the Krebs-Ringer bicarbonate buffer, $\mathrm{pH} 7.4$, in the presence of imipramine $(50$ and $100 \mu \mathrm{M})$ or DMSO (control) for $1.5 \mathrm{~h}$ at $37^{\circ} \mathrm{C}$ in the atmosphere of $5 \% \mathrm{CO}_{2}-95 \% \mathrm{O}_{2}$. The reaction was stopped with ice cold Krebs-Ringer bicarbonate buffer, pH 7.4 and muscles were used for lipids extraction and separation as described below. To determine the stimulation of glucose uptake by insulin muscle strips were incubated in the Krebs-Ringer bicarbonate buffer, $\mathrm{pH} 7.4$ at $37^{\circ} \mathrm{C}$ for $1 \mathrm{~h}$ in the atmosphere of $5 \%$ $\mathrm{CO}_{2}$ and $95 \% \mathrm{O}_{2}$ before addition of insulin and 2-D- $\left[{ }^{3} \mathrm{H}\right]$ glucose as described below.

\section{Determination of glucose metabolism}

Muscle strips were used to study insulin-induced uptake of 2-D- $\left[{ }^{3} \mathrm{H}\right]$ glucose $(0.5 \mu \mathrm{Ci} / \mathrm{ml})$ by the method of BrutmanBarazani et al. (2012). Muscle strips were incubated in the Krebs-Ringer bicarbonate buffer, $\mathrm{pH} 7.4$ at $37^{\circ} \mathrm{C}$ for $1 \mathrm{~h}$ in the atmosphere of $5 \% \mathrm{CO}_{2}$ and $95 \% \mathrm{O}_{2}$ and then treated by $10 \mathrm{nM}$ insulin or $0.9 \% \mathrm{NaCl}$ (control) for $30 \mathrm{~min}$. To study the glucose uptake muscles were washed by the same buffer and placed into the buffer, supplemented with $0.5 \mu \mathrm{Ci} / \mathrm{ml}$ of $2-\mathrm{D}-\left[{ }^{3} \mathrm{H}\right]$ glucose, and incubated for $10 \mathrm{~min}$ at $37^{\circ} \mathrm{C}$. The reaction was stopped by addition of the ice-cold Krebs-Ringer bicarbonate buffer, $\mathrm{pH} 7.4$, and muscles were washed three times in the same buffer. The muscles were lysed with 50 $\mathrm{mM} \mathrm{NaOH}$ and radioactivity of ${ }^{3} \mathrm{H}$-glucose was measured using a BETA scintillation counter. Content of protein in the samples was determined according to Lowry et al. (1951).

\section{Determination of sphingolipids turnover}

The activity of acid SMase was determined using the intact skeletal muscles lysates and [N-methyl- ${ }^{14} \mathrm{C}$-phosphorylcholine] sphingomyelin (52 mCi/mmol) ("PerkinElmer", USA), as enzyme substrate. The specific activity was adjusted by the addition of unlabeled SM. To determine activity of acid SMase, tissues were lysed in buffer containing $50 \mathrm{mmol} / \mathrm{l}$ $\mathrm{CH}_{3} \mathrm{COONa}, \mathrm{pH} 5.0,0.65 \%$ Triton $\mathrm{X}-100$. The reaction mixture contained $50 \mathrm{mmol} / \mathrm{C} \mathrm{CH}_{3} \mathrm{COONa}, \mathrm{pH} 5.0,0.65 \%$ Triton X-100, $1.5 \mathrm{mg}$ protein and 38,000 dpm [methyl- ${ }^{14} \mathrm{C}$ ] sphingomyelin in a final volume of $200 \mu \mathrm{l}$. The reaction proceeded up to $1 \mathrm{~h}$ at $37^{\circ} \mathrm{C}$ and then was terminated by the addition of $1.5 \mathrm{ml}$ of chloroform/methanol $(1: 2, \mathrm{v} / \mathrm{v})$ followed by $0.5 \mathrm{ml}$ of chloroform and $0.5 \mathrm{ml}$ of $\mathrm{H}_{2} \mathrm{O}$. The mixture was centrifuged for $5 \mathrm{~min}$ at 3,000 rpm. After phase separation, a portion of the upper, aqueous phase containing $\left[{ }^{14} \mathrm{C}\right]$ phosphorylcholine, was removed and the radioactivity determined by liquid scintillation counting. To determine the remaining [methyl- ${ }^{14} \mathrm{C}$ ] sphingomyelin, the lower phase was used.

\section{Extraction and separation of lipids}

The lipids were extracted according to the Bligh and Dyer protocol (Bligh and Dyer 1959). The chloroform phase was collected and dried in vacuum at $37^{\circ} \mathrm{C}$. The lipids were redissolved in chloroform/methanol $(1: 2, \mathrm{v} / \mathrm{v})$ and applied on the TLC plates. For ceramide and SM analysis the individual lipids were separated by TLC on Sorbfil plates (Sorbpolymer, Russia) in solvent systems $\mathrm{CH}_{3} \mathrm{CH}_{2} \mathrm{OCH}_{2} \mathrm{CH}_{3}$ (system 1) and $\mathrm{CHCl}_{3}-\mathrm{CH}_{3} \mathrm{OH}-\mathrm{H}_{2} \mathrm{O}(40: 10: 1 \mathrm{v} / \mathrm{v})$ (system 2). Lipid spots on chromatograms were identified by comparison with the standards (Sigma, USA). SM content was determined by the Bartlett technique (Bartlett 1959). For ceramide content determination, lipid spots were transferred to test tubes and eluted by a mixture of chloroform and methanol (volumes 1:1) with subsequent elution by methanol. Combined eluates were subjected to vacuum evaporation and hydrolysis in $\mathrm{HCl}$ solution $(0.5 \mathrm{~mol} / \mathrm{l})$ in methanol at $65^{\circ} \mathrm{C}$ for $15 \mathrm{~h}$. Masses of ceramides were estimated by the release of longchain compounds after hydrolysis of lipids (Babenko and Kharchenko 2012). 


\section{Statistical analysis}

Data were analyzed by one-way analysis of variance (ANOVA) followed by post hoc Fisher's protected least significant difference (Fisher PLSD) test. The results obtained represent the means \pm standard error of the mean (SEM) and deemed statistically significant when $p<0.05$. The statistical analysis was carried out with StatSoft Statistica v6.0.
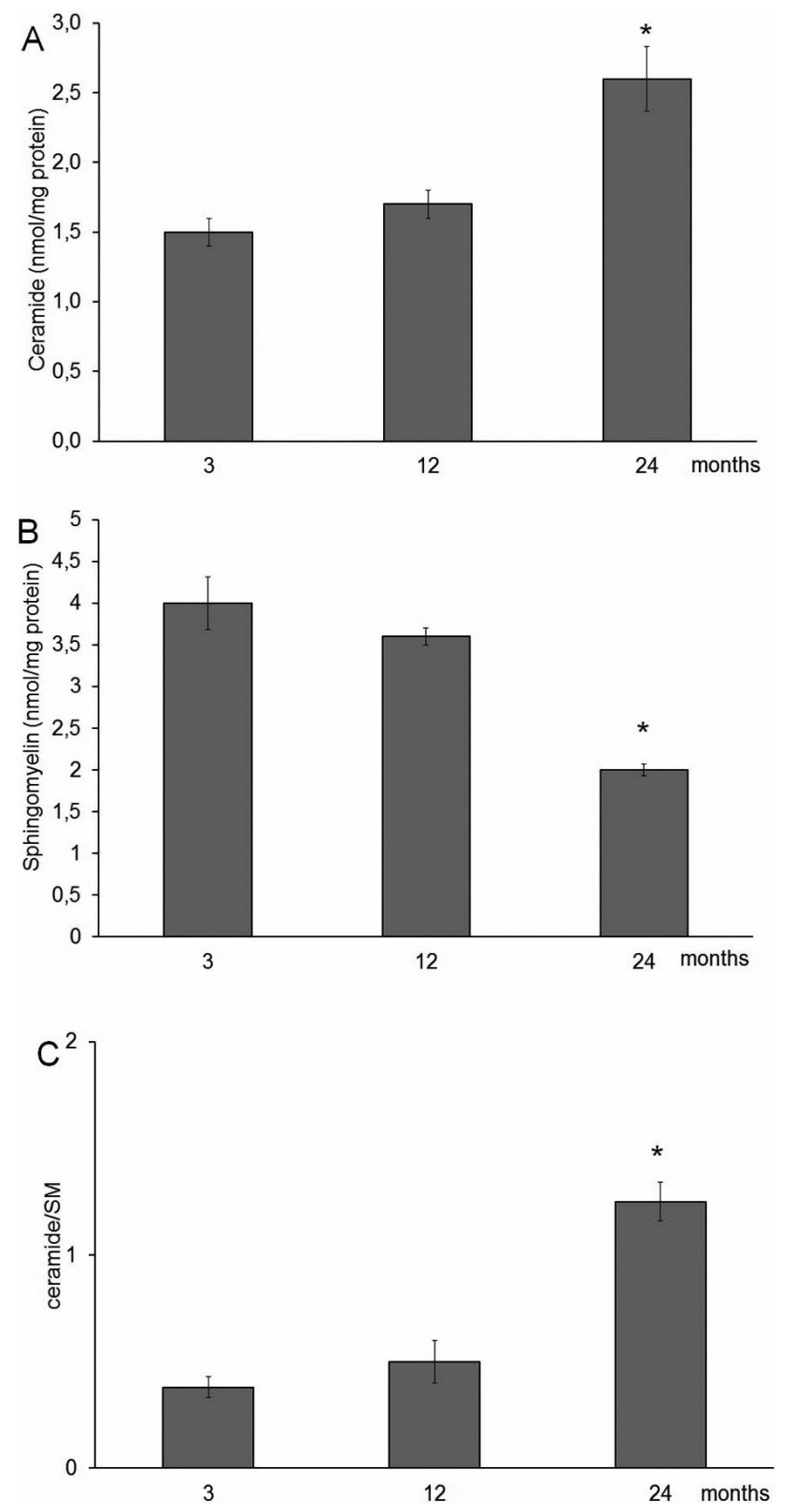

Figure 1. Ceramide and sphingomyelin levels in the extensor digitorum longus muscle of rats of different age. A. Ceramide content of the muscle ( $\mathrm{nmol} / \mathrm{mg}$ protein). B. Sphingomyelin (SM) content of the muscle (nmol/mg protein). C. Ceramide/SM ratio (nmol/ nmol) in the muscle. ${ }^{*} p<0.0524$-month-old $v$ s. 3-month-old rats.

\section{Results}

Age-dependent peculiarities of sphingolipids contents in the muscle

To study the age-dependent peculiarities of ceramide and SM contents in the muscle two adult (3-and 12-month-old) and old (24-month-old) groups of rats were used. Ceramide content (Fig. 1A) and ceramide/SM ratio progressively increased (Fig. 1C), while SM level decreased (Fig. 1B) in the muscle tissue during aging. However, ceramide (Fig. 1A) as well as ceramide/SM ratio (Fig. 1C) and SM level (Fig. 1B) in the muscle of 12-month-old rats was not differ from that of 3-month-old animals, while ceramide content (Fig. 1A) was significantly increase and SM level decrease (Fig. 1B) in the muscle of 24-month-old animals in contrast of younger rats. Simultaneous increase of ceramide level and ceramide/ SM ratio and decrease of SM content in the cells are usually associated with elevation of SMase activity. It can be supposed that activation of these enzymes play important role in ceramide accumulation in the muscle of 24-month-old rats. Thus, in other experiments 24-month-old rats were used to determine the impact of acid SMase in the intramuscular ceramide accumulation and reduction of the extensor digitorum longus muscle tissue response to insulin action at old age. Taking into account that sphingolipid levels in the muscle of young adult 3-month-old rats were not different from that of adult 12-month-old animals, the 3-month-old rats were used to show that drugs can improve SM turnover and muscle response to insulin in 24-month-old animal up to the level in the adult rats.

Effect of natural C16-ceramide on glucose uptake stimulation by insulin in muscles of adult rats

To be sure that extensor digitorum longus muscle is sensitive to both insulin and natural ceramide action in the next set of experiments the regulation of $2-\mathrm{D}-\left[{ }^{3} \mathrm{H}\right]$ glucose uptake by insulin in muscles of 3- and 24-month-old rats was studied. Moreover, C16-ceramide, the most prevalent in the skeletal muscle (Ferreira et al. 2010; Dobrzyn and Gorski 2002; Dumitru et al. 2007), was used for treatment of 3-month-old rats. Long-term treatment of the 3-monthold animals by C16-ceramide led to the accumulation of ceramide, but not SM in the extensor digitorum longus muscle (Fig. 2A). The two-fold increase of glucose uptake by insulin was determined in the muscle strips of untreated (Fig. 2B) and C16-ceramide solvent-treated 3-month-old rats (Fig. 2C). However, response of muscle strips to insulin action of 24-month-old animals (Fig. 2B) and muscle strips of 3-month-old rats treated by C16-ceramide (Fig. 2C) was significantly reduced in contrast to adult or control adult rats, respectively. Results obtained demonstrated that exogenous 
natural C16-ceramide treatment led to old age-like increase of intramuscular ceramide content, which followed by reduction of insulin-stimulated glucose uptake by muscle of
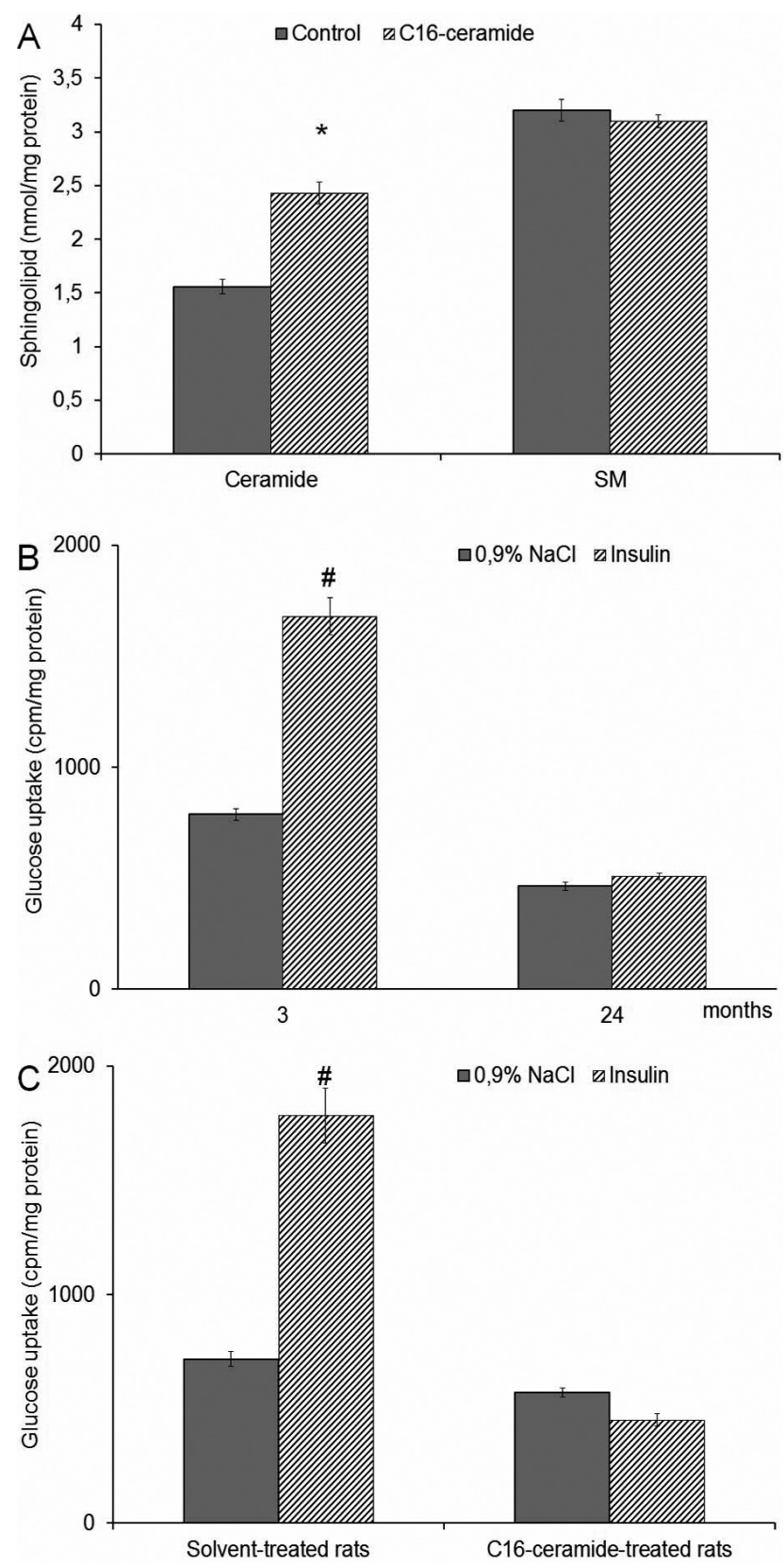

Figure 2. Treatment of 3-month-old rats by C16-ceramide increases ceramide content and reduces extensor digitorum longus muscle response to insulin action. A. Ceramide and sphingomyelin (SM) content of muscles (nmol/mg protein). B. 2-D- $\left[{ }^{3} \mathrm{H}\right]$ glucose uptake by the muscle strips stimulated by insulin or by the control strips of 3 - and 24-month-old rats. C. 2-D- $\left[{ }^{3} \mathrm{H}\right]$ glucose uptake by the muscle strips stimulated by insulin or in the control strips of 3-month-old control and C16-ceramide-treated rats. ${ }^{*} p<0.05 \mathrm{C} 16$-ceramide-treated $v s$. control; ${ }^{\#} p<0.05$ insulin-treated vs. $0.9 \% \mathrm{NaCl}$-treated muscles. adult animals. Taking into account that intramuscular SM content was not changed under C16-ceramide treatment we can suppose that ceramide accumulation plays important role in decrease of insulin-stimulated glucose uptake by the target tissue.

\section{Effect of inhibitors of acid SMase on sphingolipid turnover in the skeletal muscle of old rats}

In the present paper to study the acid SMase-dependent ceramide accumulation in the extensor digitorum longus muscle imipramine- or zoledronic acid-treated 24-monthold rats were used. Imipramine or zoledronic acid treatment of 24-month-old rats decreased acid SMase activity in the extensor digitorum longus muscle (Fig. 3). The both drugs decreased $\left[{ }^{14} \mathrm{C}\right]$ phosphorylcholine release (Fig. 3A)
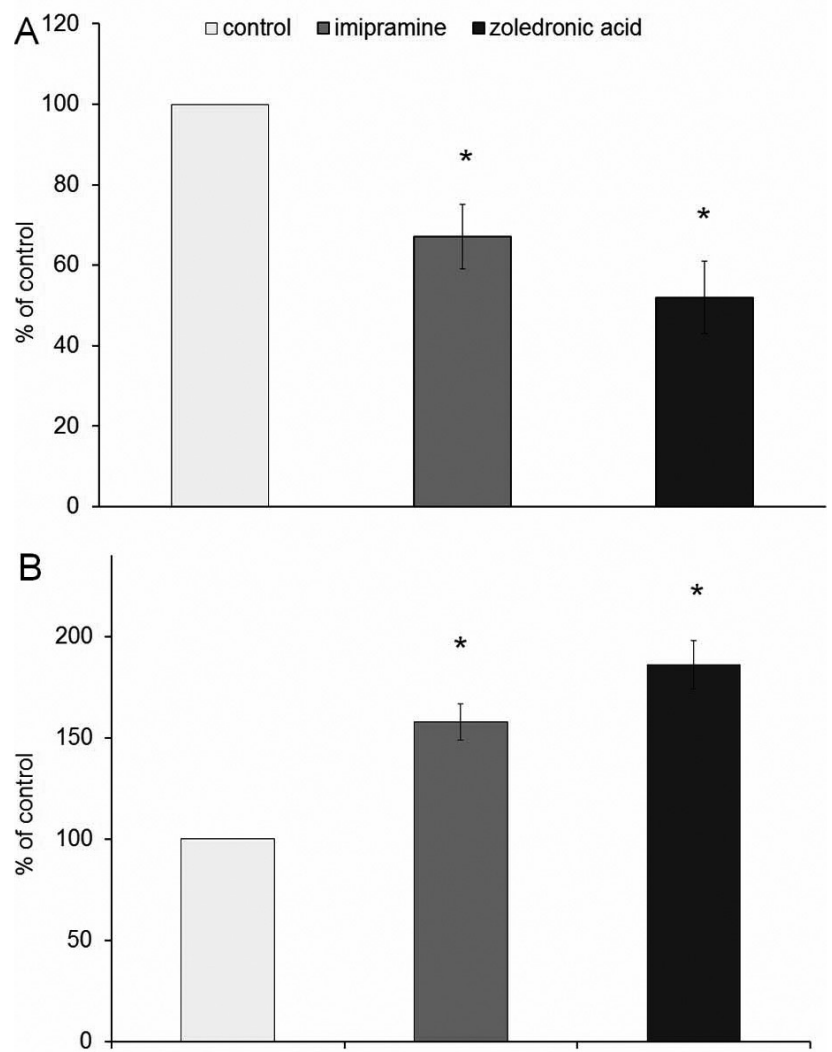

Figure 3. Imipramine and zoledronic acid inhibits the acid sphingomyelinase activity in the extensor digitorum longus muscle of 24-month-old rats. Rats were injected intramuscularly by drugs or $0.9 \% \mathrm{NaCl}$ (control) as described in the "Materials and Methods". To determine the enzyme activity [methyl- ${ }^{14} \mathrm{C}$-phosphorylcholine] sphingomyelin was used. $\left[{ }^{14} \mathrm{C}\right]$ phosphorylcholine release $(\mathbf{A})$ and $\left[\mathrm{N}\right.$-methyl- ${ }^{14} \mathrm{C}$-phosphorylcholine] sphingomyelin content (B) were determined as described in the "Materials and Methods". ${ }^{*} p<$ 0.05 drug-treated $v s$. control. 

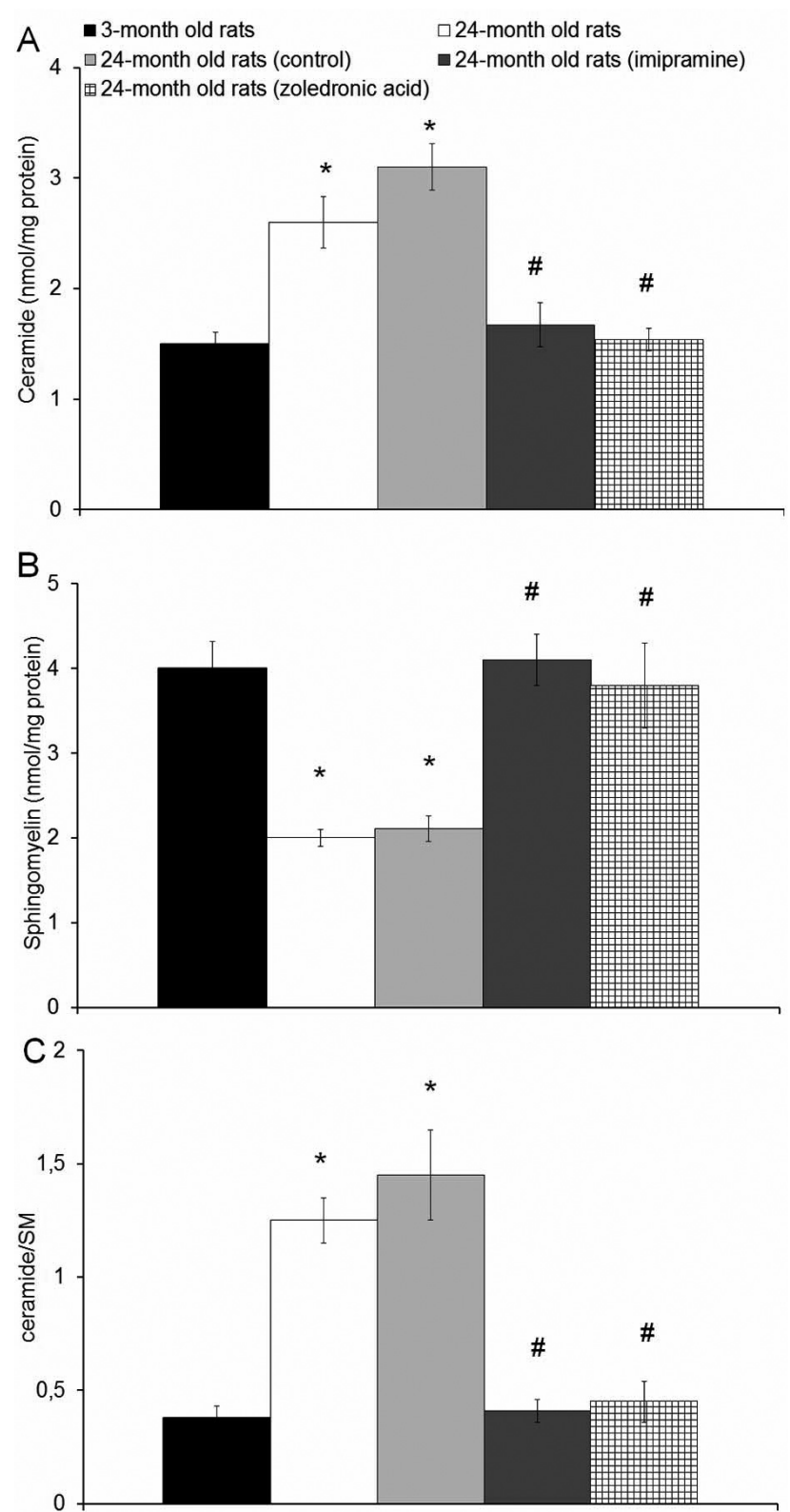

Figure 4. Effect of imipramine and zoledronic acid on sphingolipids content of the extensor digitorum longus muscle of 24-month-old rats. A. Ceramide content of the muscle (nmol/mg protein). B. Sphingomyelin (SM) content of the muscle (nmol/mg protein). C. Ceramide/ $\mathrm{SM}$ ratio $(\mathrm{nmol} / \mathrm{nmol})$ in the muscle. In the experiments 3 - and 24-month-old untreated rats as well as drug- and drug solvent-treated 24-month-old animals were used. The 24-month-old rats were injected by imipramine intramuscularly daily for 14 days $(10 \mathrm{mg} / \mathrm{kg}$ body weight) or by zoledronic acid intramuscularly $(0.15 \mathrm{mg} / \mathrm{kg}$ body weight) for 10 days, one time in two days. Here control rats for imipramine-treated group of animals were used as no differences were determined between control animals for zoledronic acid- and imipramine-treated animals. Control rats injected by $0.9 \% \mathrm{NaCl}$ intramuscularly daily for 14 days. Lipids were analyzed as described in the "Materials and Methods". $p<0.0524$-month-old $v$ s. 3-month-old rats; ${ }^{\#} p<0.05$ drug-treated 24-month-old vs. control 24-month-old rats. and [N-methyl- ${ }^{14} \mathrm{C}$-phosphorylcholine] sphingomyelin degradation (Fig. 3B). Moreover, imipramine as well as zoledronic acid nullified age-dependent ceramide accumulation (Fig. 4A) and SM content drop (Fig.4B). In addition, acid SMase inhibitors prevented increase of ceramide/SM ratio in the muscle of 24-month-old rats (Fig. 4C). To avoid the central effect of imipramine the next set of experiments were done on isolated muscle strips treated with drug. In the present paper imipramine decreased ceramide content and ceramide/SM ratio and increased SM level in the isolated extensor digitorum longus muscle strips in contrast to controls (Fig.5A). Treatment of "old" muscle strips by
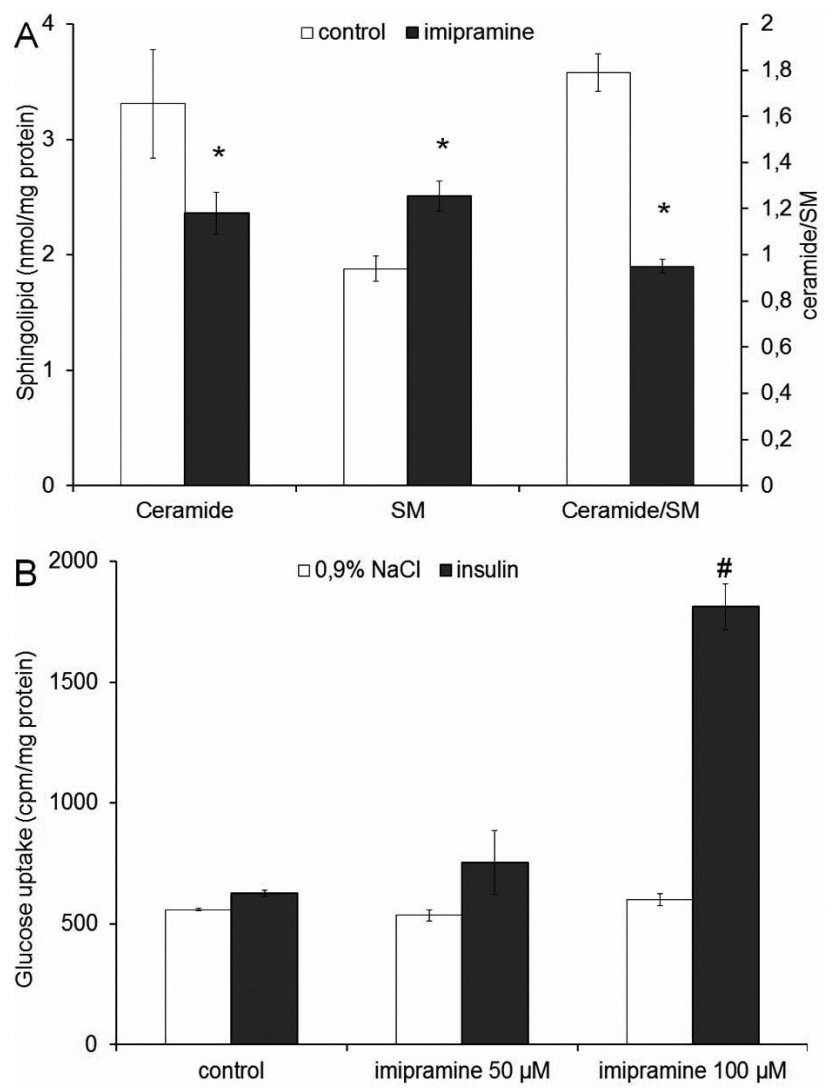

Figure 5. Imipramine treatment of the extensor digitorum longus muscle of 24-month-old rats improves sphingolipids content and muscle response to insulin action. A. Ceramide and sphingomyelin (SM) content of the muscle ( $\mathrm{nmol} / \mathrm{mg}$ protein), and ceramide/SM ratio $(\mathrm{nmol} / \mathrm{nmol})$ in the muscle. B. $2-\mathrm{D}-\left[{ }^{3} \mathrm{H}\right]$ glucose uptake by the muscle strips stimulated by insulin or by the control strips. To study the prime effect of imipramine on sphingolipids content the isolated muscle strips of 24 -month-old rats were treated by $100 \mu \mathrm{M}$ of drug or DMSO (control) for $1.5 \mathrm{~h}$. To study effect of imipramine on the insulin-stimulated glucose uptake, isolated muscle strips were treated by 50 and $100 \mu \mathrm{M}$ of drug or DMSO as described in the "Materials and Methods". ${ }^{\star} p<0.05$ drug-treated $v$ s. control; ${ }^{\#} p<0.01$ insulintreated vs. $0.9 \% \mathrm{NaCl}$-treated. 
imipramine $(100 \mu \mathrm{M})$ decreased significantly acid SMase activity, as compared with controls (data not shown). These results clearly demonstrated that increase of ceramide content and decrease of SM level in the muscle at old age depended on acid SMase activation and that imipramine directly inhibited sphingolipid turnover in the extensor digitorum longus muscle.

\section{Effect of inhibitors of acid SMase on insulin-stimulated glucose uptake by the skeletal muscle of old rats}

The long-term imipramine, as well as zoledronic acid treatment of 24-month-old rats increased significantly the extensor digitorum longus muscle sensitivity to insulin action. Drugs increased insulin-stimulated 2-D- $\left[{ }^{3} \mathrm{H}\right]$ glucose uptake by the extensor digitorum longus muscle strips of 24-monthold animals (Fig. 6) to the level close to that of 3-month-old rats (Fig. 2B). However, imipramine slightly reduced glucose uptake in the non-stimulated muscle strips, while zoledronic acid did not alter this process in the insulin-untreated muscle. Short-term imipramine treatment of isolated muscle strips of 24-month-old rats led to $\sim$ four-fold increase of insulin-stimulated glucose uptake and did not change glucose metabolism in the non-stimulated tissues (Fig. 5B).

\section{Discussion}

Majority of studies have demonstrated that ceramide is the most potent inhibitor of various key points in insulin signal transduction, such as protein kinase $\mathrm{Akt} / \mathrm{PKB}$ and protein kinase $\mathrm{C \zeta}(\mathrm{PKC})$, protein phosphatase 2A (PP2A), Glut4 and phospholipase D. Using insulin responsive cells and as a role short-chain synthetic ceramides it was shown that ceramide inhibits insulin-stimulated glucose metabolism, blocking protein kinase Akt/PKB activity (Holland and Summers 2008) and translocation to the plasma membranes (Stratford et al. 2001). Ceramides stabilize interactions between Akt/PKB and atypical PKC isoform - PKC (Fox et al. 2007; Hajduch et al. 2008). Ceramide-induced activation of PP2A can lead to Akt/PKB dephosphorylation and thus prevents stimulation of glucose uptake by insulin (Ugi et al. 2004). At the same time, inhibition of the PP2A by okadaic acid prevents the ceramide-induced disruption of insulin signaling pathway in the $\mathrm{C} 2 \mathrm{C} 12$ myotubes (Chavez et al. 2003), PC12 neurons (Salinas et al. 2000), adipocytes (Teruel et al. 2001) and human glioblastoma cell line (Zinda et al. 2001). Moreover, ceramide can inhibit glucose uptake/ glycogen synthesis via decrease of Glut 4 translocation to cellular membranes (JeBailey et al. 2007) or Glut4 transcription (Long and Pekala 1996) and phospholipase D inhibition (Babenko and Kharchenko 2015c). Elevation of ceramide content and reduction of insulin sensitivity in muscle tissues

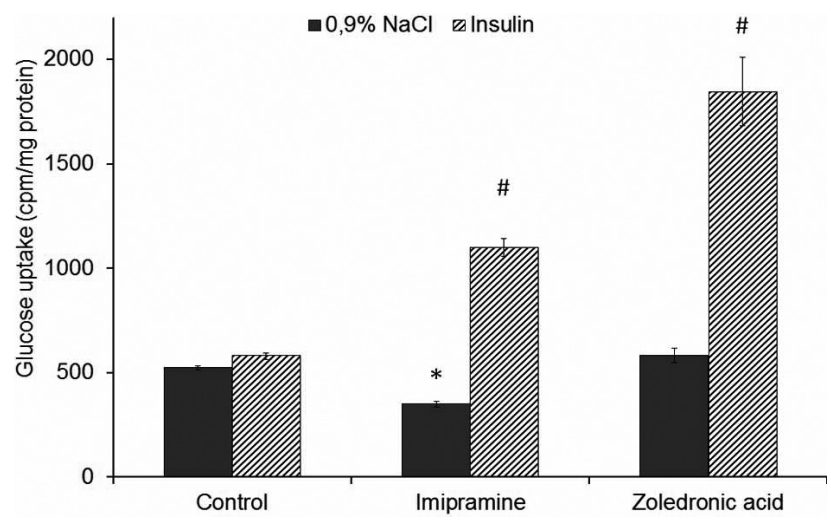

Figure 6. Imipramine and zoledronic acid treatment of the 24-monthold rats increases extensor digitorum longus muscles response to insulin action. Rats were injected intramuscularly by drugs or $0.9 \%$ $\mathrm{NaCl}$ (control) and insulin-stimulated glucose uptake by the muscle strips was determined as described in the "Materials and Methods". ${ }^{*} p<0.05$ drug-treated $v$ s. control $0.9 \% \mathrm{NaCl}$-treated, ${ }^{\#} p<0.05$ insulintreated $v s .0 .9 \% \mathrm{NaCl}$-treated.

was determined in human studies in obese and type 2 diabetic patients (Adams et al. 2004; Moro et al. 2009; Coen et al. 2010; Amati et al. 2011; Søgaard et al. 2016) and in obese experimental animals (Holland and Summers 2008). Furthermore, studies of 18-80 year-old patients demonstrated that old and obese as well as insulin resistant humans have an elevated total and long-chain ceramide species content in the skeletal muscle tissue in contrast to younger and lean ones (de la Maza et al. 2015). Accumulation of ceramides in the insulin responsive tissues, such as liver (Babenko and Shakhova 2006), brain (Babenko and Shakhova 2014a) and some types of skeletal muscles: soleus and gastrocnemius (Babenko et al. 2016; Rivas et al. 2016) and extensor digitorum longus muscle (Fig. 1A) has been determined at old age. Age-dependent ceramide accumulation in the hepatocytes and brain cortex was followed by a decrease of insulin-stimulated glucose uptake and glycogen synthesis (Babenko and Kharchenko 2012, 2015a). Similar results were obtained in the present work. Extensor digitorum longus muscle sensitivity to insulin action significantly reduced at old age, in contrast to adult animals. Treatment of adult rats by natural C16-ceramide was followed by old age-like intramuscular ceramide accumulation and reduction of insulin-stimulated glucose uptake. In addition, treatment of muscle $\mathrm{C} 2 \mathrm{C} 12$ cells by a cell-permeable ceramide inhibits insulin-stimulated Akt serine phosphorylation and activation which triggered insulin resistance (Jadhav et al. 2013).

Ceramide not only reduced target cells' sensitivity to insulin action but also led to a premature senescence of the cancerous cells (Chen et al. 2010; Leontieva et al. 2011; Saddoughi and Ogretmen 2013), endothelial cells (Venable and Yin 2009), fibroblasts (Venable et al. 1995) and muscle 
cells (Jadhav et al. 2013). Treatment of proliferating C2C12 myoblasts with $\mathrm{C} 2$-ceramide induced expression of senescence marker - $\beta$-galactosidase and cell cycle inhibitory proteins, such as p16, p21 and p53. C2-ceramide also reduces cell proliferation and response to insulin action (Jadhav et al. 2013). C2-ceramide decreases Akt phosphorylation in both untreated and insulin-stimulated myoblasts, which can be improved by glucose lowering agent, metformin. Moreover, metformin partly reversed cellular senescence induced by ceramide. Thus, it has become evident that insulin signaling in the skeletal muscle is extremely sensitive to ceramide accumulation and that close relation exists between age-dependent resistance of cells to insulin action and intramuscular ceramide level increase. However, the mechanism of ceramide overproduction at an old age in the skeletal muscle is still unknown.

Notably, that inhibition of key enzyme of ceramide synthesis de novo in the diet-induced obese or $o b / o b$ mice improved both senescence-associated secretory phenotype and glucose and insulin tolerance (Yang et al. 2009). Significant increase of expression of SPT, as well as neutral SMase has been determined in the medial gastrocnemius, but not in the soleus muscle of 24-26-month-old male F344/BN rats, in contrast to 7-8-month-old animals (Russ et al. 2015). No age-dependent differences in expression of acid SMase and neutral CDase have been determined in the gastrocnemius and soleus muscles. However, previously we have determined that elevated acid SMase activity at old age could lead to ceramide accumulation in the gastrocnemius and soleus muscles of Wistar male rats (Babenko et al. 2016). Widely used acid SMase inhibitors, imipramine and zoledronic acid (Kölzer et al. 2003; Roth et al. 2009; Arenz 2010; ; Jenkins et al. 2010; Kornhuber et al. 2010; Canals et al. 2011), improve SM turnover in different tissues. Multiple mechanisms by which some antidepressants mediate their effects on glucose metabolism (psychobehavioural, neurohormonal, anti-inflammatory and intracellular effects) have been determined. Antidepressants may be involved in regulation of glucoseinsulin homeostasis through central mechanisms at the level of the hypothalamus and hippocampus. Both beneficial and harmful effects of antidepressants on glucose homeostasis have been evaluated. Up to now it is not clear if tricyclic antidepressants influence glucose-insulin homeostasis via acid SMase inhibition in the insulin responsive tissues or via central mechanisms. Thus, in the present paper in addition to experiments on imipramine-treated rats treatment of isolated muscle strips by imipramine was used. Our results showed for the first time that treatment of 24-month-old rats or isolated "old" extensor digitorum longus muscle by imipramine or zoledronic acid reduced acid SMase activity and improved ceramide and SM levels and ceramide/SM ratio. This data demonstrated involvement of acid SMase in the age-dependent sphingolipid turnover dysregulation in the extensor digitorum longus muscle. Moreover, imipramine improved muscle tissue sensitivity to insulin action at old age primarily inhibiting acid SMase. Drug direct effect on muscle can be dependent on reduction of the level of ceramide, negative regulator of insulin-stimulated signaling pathways, and not be the reason of imipramine action on brain and other tissues. Taken together, these results and data published previously (Babenko and Kharchenko 2012, 2015a) clearly demonstrate that there is a specific pathway of ceramide production for each insulin-responsive tissue which induces the reduction of cells sensitivity to insulin action at old age. It is worth to note, that not only ceramide accumulation, but the pathway of its production can be extremely important for cell response. Taking into account different physiological consequences of insulin action in each of target tissue ceramide accumulation can be followed by specific pathophysiology. Overexpression of acid SMase plays an important role in SFD- and alcohol-induced inflammation, liver insulin resistance and steatosis, while inhibition of acid SMase with amitriptyline protects wild type mice against liver injury (Garcia-Ruiz et al. 2015). On the other hand, $\mathrm{C} 2 \mathrm{C} 12$ myotubes treatment with palmitic acid increases expression of neutral SMase genes which is associated with ceramide synthesis through the salvage pathway and insulin resistance (Verma et al. 2014). Inhibition of neutral SMase by an inhibitor (GW4869) partially reverts the palmitate-induced insulin resistance and improves metabolic functions of myotubes.

Previously we reported that both long- and short-term treatment of 24-month-old rats by N-acetylcysteine (NAC) led to a decrease of ceramide content, but did not nullify age-dependent ceramide accumulation in the extensor digitorum longus muscle (Babenko et al. 2015). NAC increases gluthathione (GSH) content and insulin-stimulated glucose uptake in the muscle of old rats. Beneficial effect of NAC on sphingolipid turnover can be imitated by specific inhibitor of neutral SMase, GW4869, in in vitro studies. Suggestion has been made that neutral SMase plays important role in ceramide accumulation in the extensor digitorum longus muscle at old age. It is known, that oxidative stress and inflammatory cytokines can activate both neutral and acid SMases. Ceramide accumulation is required in order for cytokines to induce insulin resistance in skeletal muscles (Gamard et al. 1997; Strle et al. 2004; Demarchi et al. 2005; Holland et al. 2011). Inhibition of neutral and acid SMase activity and ceramide synthesis by GSH, D609 and fumonisin B1, respectively, prevented tumor necrosis factor $\alpha$ (TNF- $\alpha$ )- and interleukin $1 \beta$ (IL-1 $\beta$ )-induced resistance of myotubes to insulin-like growth factor I action (IGF) (Strle et al. 2004). Increase of expression of inflammatory markers, such as Toll-like receptor 2, TNF- $\alpha$ and IL- $1 \beta$, as well as ceramide level were found in the skeletal muscles of old animals (Rivas et al. 2016). Age-dependent ceramide accumulation leads to diminished 
anabolic signaling response to insulin and contributes to skeletal muscle loss. Recently it was shown that treatment of mature $\mathrm{C} 2 \mathrm{C} 12$ myotubes or diaphragm fiber bundles by exogenous SMase led to increase of total ceramide content and levels of numerous ceramide species and production of ROS followed by depressed muscle force and accelerated fatigue (Ferreira et al. 2010; Loehr et al. 2015). SMase-induced ROS production and malfunction of skeletal muscles can be prevented by NAC treatment (Ferreira et al. 2010). It is noteworthy, that muscle weakness and fatigue as well as abnormal redox signaling and oxidative stress are frequently associated with aging (Scheel-Toellner et al. 2004; Colavitti and Finkel 2005). Age-dependent decrease of neutral SMase negative regulator (GSH) content can be increased by NAC treatment of insulin responsive tissues: liver, brain and extensor digitorum longus muscle (Babenko et al. 2012; Babenko and Shakhova 2014b; Babenko et al. 2015). NAC or GSH treatment was followed by an increase of insulin-stimulated glucose uptake and glycogen synthesis in the target cells of 24-month-old animals. However, insulin response was still stronger in 3-month-old untreated rats. Thus, it cannot be excluded that overproduction of inflammatory cytokines at old age can induce acid SMase-dependent ceramide accumulation followed by oxidative stress-dependent neutral SMase activation and reduction of "old" muscle cells sensitivity to insulin action. Other experiments are needed to elucidate these conclusions.

In summary, this study demonstrated that acid SMasedependent ceramide production and accumulation in the extensor digitorum longus muscle at old age plays an important role in the reduction of insulin-stimulated glucose uptake. Progressive increase of ceramide content was determined in the muscle tissues during aging. Ceramide accumulation in the muscles of 24-month-old rats was followed by SM content drop and ceramide/SM ratio increase. Dysregulation of SM turnover as well as insulin-stimulated glucose uptake in the skeletal muscles of old rats can be abolished by treatment with functional inhibitor of acid SMase (imipramine) and specific inhibitor (zoledronic acid). Both long-term (in vivo) and short-term (in vitro) effects of imipramine were determined. These findings demonstrated prime imipramine effect on SM turnover and insulin signaling in the "old" skeletal muscle which was not dependent on drug action in brain or other tissues. These results indicated that enhanced acid SMase-dependent ceramide production was required for development of resistance of aged extensor digitorum longus muscle to insulin action. However, other pathways of sphingolipid turnover may be involved in ceramide content elevation in the muscle of old animals. Manipulating acid SMase activity and ceramide content in the aged skeletal muscle may be the strategy for treating abnormal glucose metabolism regulation. Drugs (imipramine and zoledronic acid) which are licensed for medical use in humans were used for the first time for treatment of old age-associated insulin resistance of skeletal muscles.

Acknowledgement. This work was supported by the grant from the Ministry of Science and Education of Ukraine (State registration No. 0111U010555). Authors declare no conflict of interest and no financial interest in the publication of this manuscript.

\section{References}

Adams JM, 2nd, Pratipanawatr T, Berria R, Wang E, DeFronzo RA, Sullards MC, Mandarino LJ (2004): Ceramide content is increased in skeletal muscle from obese insulin-resistant humans. Diabetes 53, 25-31 https://doi.org/10.2337/diabetes.53.1.25

Amati F, Dube JJ, Alvarez-Carnero E, Edreira MM, Chomentowski P, Coen PM, Switzer GE, Bickel PE, Stefanovic-Racic M, Toledo FG, et al. (2011): Skeletal muscle triglycerides, diacylglycerols, and ceramides in insulin resistance: another paradox in endurance-trained athletes? Diabetes $\mathbf{6 0}$, 2588-2597 https://doi.org/10.2337/db10-1221

Arenz C (2010): Small molecule inhibitors of acid sphingomyelinase. Cell. Physiol. Biochem. 26, 1-8 https://doi.org/10.1159/000315100

Babenko NA, Shakhova EG (2006): Effects of Chamomilla recutita flavonoids on age-related liver sphingolipid turnover in rats. Exp. Gerontol. 41, 32-39 https://doi.org/10.1016/j.exger.2005.08.008

Babenko NA, Kharchenko VS (2012): Ceramides inhibit phospholipase D-dependent insulin signaling in liver cells of old rats. Biochemistry Mosc. 77, 180-186 https://doi.org/10.1134/S0006297912020095

Babenko NA, Hassouneh LKM, Kharchenko VS, Garkavenko VV (2012): Vitamin E prevents the age-dependent and palmitateinduced disturbances of sphingolipid turnover in liver cells. Age (Dordr.) 34, 905-915 https://doi.org/10.1007/s11357-011-9288-3

Babenko NA, Shakhova EG (2014a): Long-term food restriction prevents aging-associated sphingolipid turnover dysregulation in the brain. Arch. Gerontol. Geriatr. 58, 420-426 https://doi.org/10.1016/j.archger.2013.12.005

Babenko NA, Shakhova OG (2014b): Effect of an inhibitor of sphingomyelinases, $\mathrm{n}$-acetylcysteine, on cognitive functions in old rats. Neurophysiology 46, 180-182 https://doi.org/10.1007/s11062-014-9426-5

Babenko NA, Timofiǐchuk OA, Belyĭ AN (2015): Role of neutral sphingomyelinase in age-dependent muscle insulin resistance development and its improvement with $\mathrm{N}$-acetylcysteine. Adv. Gerontol. 28, 104-108

Babenko NA, Kharchenko VS (2015a): Effects of inhibitors of key enzymes of sphingolipid metabolism on insulin-induced glucose uptake and glycogen synthesis in liver cells of old rats. Biochemistry Mosc. 80, 104-112 https://doi.org/10.1134/S0006297915010125 
Babenko NA, Kharchenko VS (2015b): Effects of aging and experimentally induced modifications of signal pathways on insulininduced shifts of glucose metabolism in the rat neocortex. Neurophysiology 47, 16-22 https://doi.org/10.1007/s11062-015-9491-4

Babenko NA, Kharchenko VS (2015c): Modulation of insulin sensitivity of hepatocytes by the pharmacological downregulation of phospholipase D. Int. J. Endocrinol. 2015, 794838 https://doi.org/10.1155/2015/794838

Babenko NA, Garkavenko VV, Storozhenko GV, Timofiychuk OA (2016): Role of acid sphingomyelinase in the age-dependent dysregulation of sphingolipids turnover in the tissues of rats. Gen. Physiol. Biophys. 35, 195-205 https://doi.org/10.4149/gpb_2015046

Bartlett GR (1959): Phosphorus assay in column chromatography. J. Biol. Chem. 234, 466-468

Blachnio-Zabielska A, Baranowski M, Zabielski P, Gorski J (2010): Effect of high fat diet enriched with unsaturated and diet rich in saturated fatty acids on sphingolipid metabolism in rat skeletal muscle. J. Cell Physiol. 225, 786-791 https://doi.org/10.1002/jcp.22283

Blachnio-Zabielska A, Zabielski P, Baranowski M, Gorski J (2011) Aerobic training in rats increases skeletal muscle sphingomyelinase and serine palmitoyltransferase activity, while decreasing ceramidase activity. Lipids 46, 229-238 https://doi.org/10.1007/s11745-010-3515-z

Bligh EG, Dyer WJ (1959): A rapid method of total lipid extraction and purification. Can. J. Biochem. Physiol. 37, 911-917 https://doi.org/10.1139/y59-099

Brutman-Barazani T, Horovitz-Fried M, Aga-Mizrahi Sh, Brand Ch, Brodie Ch, Rosa J, Sampson SR (2012): Protein kinase C $\delta$ but not $\mathrm{PKC} \alpha$ is involved in insulin-induced glucose metabolism in hepatocytes. J. Cell. Biochem. 113, 2064-2076 https://doi.org/10.1002/jcb.24078

Canals D, Perry DM, Jenkins RW, Hannun YA (2011): Drug targeting of sphingolipid metabolism: sphingomyelinases and ceramidases. Br. J. Pharmacol. 163, 694-712 https://doi.org/10.1111/j.1476-5381.2011.01279.x

Cawthorn WP, Sethi JK (2008): TNF- $\alpha$ and adipocyte biology. FEBS Lett. 582, 117-131 https://doi.org/10.1016/j.febslet.2007.11.051

Chavez JA, Knotts TA, Wang LP, Li G, Dobrowsky RT, Florant GL, Summers SA (2003): A role for ceramide, but not diacylglycerol, in the antagonism of insulin signal transduction by saturated fatty acids. J. Biol. Chem. 278, 10297-10303 https://doi.org/10.1074/jbc.M212307200

Chavez JA, Summers SA (2003): Characterizing the effects of saturated fatty acids on insulin signaling and ceramide and diacylglycerol accumulation in 3T3-L1 adipocytes and C2C12 myotubes. Arch. Biochem. Biophys. 419, 101-109 https://doi.org/10.1016/j.abb.2003.08.020

Chen JY, Hwang CC, Chen WY, Lee J.C, Fu TF, Fang K, Chu YC, Huang YL, Lin JC, Tsai WH, et al. (2010) Additive effects of C (2)-ceramide on paclitaxel-induced premature senescence of human lung cancer cells. Life Sci. 87, 350-357 https://doi.org/10.1016/j.lfs.2010.06.017

Coen PM, Dube JJ, Amati F, Stefanovic-Racic M, Ferrell RE, Toledo FG, Goodpaster BH (2010): Insulin resistance is associated with higher intramyocellular triglycerides in type I but not type II myocytes concomitant with higher ceramide content. Diabetes 59, 80-88

https://doi.org/10.2337/db09-0988

Colavitti R, Finkel T (2005): Reactive oxygen species as mediators of cellular senescence. IUBMB Life 57, 277-281 https://doi.org/10.1080/15216540500091890

de la Maza MP, Rodriguez JM, Hirsch S, Leiva L, Barrera G, Bunout D (2015): Skeletal muscle ceramide species in men with abdominal obesity. J. Nutr. Health Aging 19, 389-396 https://doi.org/10.1007/s12603-014-0548-7

Demarchi F, Bertoli C, Greer PA, Schneider C (2005): Ceramide triggers an NF-B-dependent survival pathway through calpain. Cell Death Differ. 12, 512-522 https://doi.org/10.1038/sj.cdd.4401592

Dobrzyn A, Gorski J (2002): Ceramides and sphingomyelins in skeletal muscles of the rat: content and composition. Effect of prolonged exercise. Am. J. Physiol. Endocrinol. Metab. 282, E277-285 https://doi.org/10.1152/ajpendo.00151.2001

Dumitru CA, Zhang Y, Li X, Gulbins E (2007): Ceramide: a novel player in reactive oxygen species-induced signaling? Antioxid. Redox. Signal 9, 1535-1540 https://doi.org/10.1089/ars.2007.1692

Ferreira LF, Moylan JS, Gilliam LA, Smith JD, Nikolova-Karakashian M, Reid MB (2010): Sphingomyelinase stimulates oxidant signaling to weaken skeletal muscle and promote fatigue. Am. J. Physiol. Cell Physiol. 299, C552-560 https://doi.org/10.1152/ajpcell.00065.2010

Fox TE, Houck KL, O'Neill SM, Nagarajan M, Stover TC, Pomianowski PT, Unal O, Yun JK, Naides SJ, Kester M (2007): Ceramide recruits and activates protein kinase $\mathrm{C}$ zeta (PKC zeta) within structured membrane microdomains. J. Biol. Chem. 282, 12450-12457 https://doi.org/10.1074/jbc.M700082200

Gamard CJ, Dbaibo GS, Liu B, Obeid LM, Hannun YA (1997): Selective involvement of ceramide in cytokine-induced apoptosis. Ceramide inhibits phorbol ester activation of nuclear factor B. J. Biol. Chem. 272, 16474-16481 https://doi.org/10.1074/jbc.272.26.16474

Garcia-Ruiz C, Mato JM, Vance D, Kaplowitz N, FernandezCheca JC (2015): Acid sphingomyelinase-ceramide system in steatohepatitis: A novel target regulating multiple pathways. J. Hepatology 62, 219-233 https://doi.org/10.1016/j.jhep.2014.09.023

Hajduch E, Turban S, Le Liepvre X, Le Lay S, Lipina C, Dimopoulos N, Dugail I, Hundal HS (2008): Targeting of PKC zeta and PKB to caveolin-enriched microdomains represents a crucial step underpinning the disruption in PKB-directed signalling by ceramide. Biochem J. 410, 369-379 https://doi.org/10.1042/BJ20070936

Holland WL, Brozinick JT, Wang LP, Hawkins ED, Sargent KM, Liu Y, Narra K, Hoehn KL, Knotts TA, Siesky A, et al. (2007): Inhibition of ceramide synthesis ameliorates glucocorticoid-, saturated-fat-, and obesity-induced insulin resistance. Cell. Metab. 5, 167-179 https://doi.org/10.1016/j.cmet.2007.01.002

Holland WL, Bikman BT, Wang LP, Yuguang G, Sargent KM, Bulchand S, Knotts TA, Shui G, Clegg DJ, Wenk MR, et al. 
(2011): Lipid-induced insulin resistance mediated by the proinflammatory receptor TLR4 requires saturated fatty acidinduced ceramide biosynthesis in mice. J. Clin. Invest. 121, 1858-1870 https://doi.org/10.1172/JCI43378

Holland WL, Summers SA (2008): Sphingolipids, insulin resistance, and metabolic disease: new insights from in vivo manipulation of sphingolipid metabolism. Endocr. Rev. 29, 381-402 https://doi.org/10.1210/er.2007-0025

Jadhav KS, Dungan CM, Williamson DL (2013): Metformin limits ceramide-induced senescence in C2C12 myoblasts. Mech. Ageing Dev. 134, 548-559 https://doi.org/10.1016/j.mad.2013.11.002

JeBailey L, Wanono O, Niu W, Roessler J, Rudich A, Klip A (2007) Ceramide- and oxidant-induced insulin resistance involve loss of insulin-dependent Rac-activation and actin remodeling in muscle cells. Diabetes 56, 394-403 https://doi.org/10.2337/db06-0823

Jenkins RW, Canals D, Idkowiak-Baldys J, Simbari F, Roddy P, Perry DM, Kitatani K, Luberto C, Hannun YA (2010): Regulated secretion of acid sphingomyelinase: implications for selectivity of ceramide formation. J. Biol. Chem. 285, 35706-35718 https://doi.org/10.1074/jbc.M110.125609

Kölzer M, Arenz C, Ferlinz K, Werth N, Schulze H, Klingenstein R, Sandhoff K (2003): Phosphatidylinositol-3,5-Bisphosphate is a potent and selective inhibitor of acid sphingomyelinase. J. Biol. Chem. 384, 1293-1298 https://doi.org/10.1515/BC.2003.144

Kornhuber J, Tripal P, Reichel M, Mühle C, Rhein C, Muehlbacher M, Gulbins E (2010): Functional Inhibitors of Acid Sphingomyelinase (FIASMAs): a novel pharmacological group of drugs with broad clinical applications. Cell. Physiol. Biochem. 26, 9-20 https://doi.org/10.1159/000315101

Leontieva OV, Demidenko ZN, Gudkov AV, Blagosklonny MV (2011): Elimination of proliferating cells unmasks the shift from senescence to quiescence caused by rapamycin. PLoS One 6, e26126 https://doi.org/10.1371/journal.pone.0026126

Lipina C, Hundal HS (2011): Sphingolipids: agents provocateurs in the pathogenesis of insulin resistance. Diabetologia 54, 1596-1607 https://doi.org/10.1007/s00125-011-2127-3

Loehr JA, Abo-Zahrah R, Pal R, Rodney GG (2014): Sphingomyelinase promotes oxidant production and skeletal muscle contractile dysfunction through activation of NADPH oxidase. Front Physiol. 5, 530

Long SD, Pekala PH (1996): Lipid mediators of insulin resistance: ceramide signalling down-regulates GLUT4 gene transcription in 3T3-L1 adipocytes. Biochem. J. 319, 179-184 https://doi.org/10.1042/bj3190179

Lowry OH, Rosebrough NJ, Farr AL, Randall RJ (1951): Protein measurement with the Folin phenol reagent. J. Biol. Chem. 193, $265-275$

Moro C, Galgani JE, Luu L, Pasarica M, Mairal A, Bajpeyi S, Schmitz G, Langin D, Liebisch G, Smith SR (2009): Influence of gender, obesity, and muscle lipase activity on intramyocel- lular lipids in sedentary individuals. J. Clin. Endocrinol. Metab. 94, 3440-3447 https://doi.org/10.1210/jc.2009-0053

Rivas DA, McDonald DJ, Rice NP, Haran PH, Dolnikowski GG, Fielding RA (2016): Diminished anabolic signaling response to insulin induced by intramuscular lipid accumulation is associated with inflammation in aging but not obesity. Am. J. Physiol. Regul. Integr. Comp. Physiol. 310, R561-569 https://doi.org/10.1152/ajpregu.00198.2015

Roth AG, Drescher D, Yang Y, Redmer S, Uhlig S, Arenz C (2009): Potent and selective inhibition of acid sphingomyelinase by bisphosphonates. Angew. Chem. Int. Ed Engl. 48, 7560-7563 https://doi.org/10.1002/anie.200903288

Russ DW, Boyd IM, McCoy KM, McCorkle KW (2015): Musclespecificity of age-related changes in markers of autophagy and sphingolipid metabolism. Biogerontology 16, 747-759 https://doi.org/10.1007/s10522-015-9598-4

Saddoughi SA, Ogretmen B (2013): Diverse functions of ceramide in cancer cell death and proliferation. Advan. Cancer Res. $117,37-58$ https://doi.org/10.1016/B978-0-12-394274-6.00002-9

Salinas M, Lopez-Valdaliso R, Martin D, Alvarez A, Cuadrado A (2000): Inhibition of PKB/Akt1 by C2-ceramide involves activation of ceramide-activated protein phosphatase in PC12 cells. Mol. Cell Neurosci. 15, 156-169 https://doi.org/10.1006/mcne.1999.0813

Scheel-Toellner D, Wang K, Assi LK, Webb PR, Craddock RM, Salmon M, Lord JM (2004): Clustering of death receptors in lipid rafts initiates neutrophil spontaneous apoptosis. Biochem. Soc. Trans. 32, 679-681 https://doi.org/10.1042/BST0320679

Smith ME, Tippetts TS, Brassfield ES, Tucker BJ, Ockey A, Swensen AC, Anthonymuthu TS, Washburn TD, Kane DA, Prince JT, et al. (2013): Mitochondrial fission mediates ceramide-induced metabolic disruption in skeletal muscle. Biochem. J. 456, 427-439 https://doi.org/10.1042/BJ20130807

Søgaard D, Østergård T, Blachnio-Zabielska AU, Baranowski M, Vigelsø AH, Andersen JL, Dela F, Helge JW (2016): Training does not alter muscle ceramide and diacylglycerol in offsprings of type 2 diabetic patients despite improved insulin sensitivity. J. Diabetes Res. 2016, 1-12 https://doi.org/10.1155/2016/2372741

Stratford S, DeWald DB, Summers SA (2001): Ceramide dissociates 3 '-phosphoinositide production from pleckstrin homology domain translocation. Biochem. J. 354, 359-368 https://doi.org/10.1042/bj3540359

Strle K, Broussard SR, McCusker RH, Shen WH, Johnson RW, Freund GG, Dantzer R, Kelley KW (2004): Proinflammatory cytokine impairment of insulin-like growth factor I-induced protein synthesis in skeletal muscle myoblasts requires ceramide. Endocrinology 145, 4592-4602 https://doi.org/10.1210/en.2003-1749

Summers SA (2006): Ceramides in insulin resistance and lipotoxicity. Prog. Lipid Res. 45, 42-72

https://doi.org/10.1016/j.plipres.2005.11.002

Summers SA (2010): Sphingolipids and insulin resistance: the five Ws. Curr. Opin. Lipidol. 21, 128-135 
https://doi.org/10.1097/MOL.0b013e3283373b66

Teruel T, Hernandez R, Lorenzo M (2001): Ceramide mediates insulin resistance by tumor necrosis factor-alpha in brown adipocytes by maintaining Akt in an inactive dephosphorylated state. Diabetes 50, 2563-2571 https://doi.org/10.2337/diabetes.50.11.2563

Ugi S, Imamura T, Maegawa H, Egawa K, Yoshizaki T, Shi K, Obata T, Ebina Y, Kashiwagi A, Olefsky JM (2004): Protein phosphatase $2 \mathrm{~A}$ negatively regulates insulin's metabolic signaling pathway by inhibiting Akt (protein kinase B) activity in 3T3-L1 adipocytes. Mol. Cell Biol. 24, 8778-8789 https://doi.org/10.1128/MCB.24.19.8778-8789.2004

Venable ME, Lee JY, Smyth MJ, Bielawska A, Obeid LM (1995): Role of ceramide in cellular senescence. J. Biol. Chem. 270, 30701-30708 https://doi.org/10.1074/jbc.270.51.30701

Venable ME, Yin X (2009): Ceramide induces endothelial cell senescence. Cell Biochem. Funct. 27, 547-551 https://doi.org/10.1002/cbf.1605
Verma MK, Yateesh AN, Neelima K, Pawar N, Sandhya K, Poornima J, Lakshmi MN, Yogeshwari S, Pallavi PM, Oommen AM, et al. (2014): Inhibition of neutral sphingomyelinases in skeletal muscle attenuates fatty-acid induced defects in metabolism and stress. Springerplus 3, 255 https://doi.org/10.1186/2193-1801-3-255

Yang G, Badeanlou L, Bielawski J, Roberts AJ, Hannun YA, Samad $\mathrm{F}$ (2009): Central role of ceramide biosynthesis in body weight regulation, energy metabolism, and the metabolic syndrome. Am. J. Physiol. Endocrinol. Metab. 297, E211-224 https://doi.org/10.1152/ajpendo.91014.2008

Zinda MJ, Vlahos CJ, Lai MT (2001): Ceramide induces the dephosphorylation and inhibition of constitutively activated Akt in PTEN negative U87mg cells. Biochem. Biophys. Res. Commun. 280, 1107-1115

https://doi.org/10.1006/bbrc.2000.4248

Received: January 14, 2017

Final version accepted: May 24, 2017 